\title{
The effect of national culture on the association between profitability and corporate social and environmental disclosure: a meta-analysis
}

\author{
Hichem Khlif \\ Associate Professor of Accounting \\ University of Monastir \\ Tunisia \\ Khaled Hussainey \\ Professor of Accounting \\ Plymouth University \\ UK \\ Imen Achek \\ Ph.D. student in Accounting and Finance, \\ University of Manouba \\ Tunisia \\ Forthcoming \\ Meditari Accountancy Research \\ February 2015
}

The authors gratefully acknowledge the helpful comments and suggestions from the two anonymous reviewers and the Editor-in-Chief; Charl de Villiers, of Meditari Accountancy Research. 


\begin{abstract}
:
Research type: review

Purpose: This paper aims to investigate the moderating effect of cultural dimensions (masculinity; individualism; and long term orientation) on the association between profitability and corporate social and environmental disclosure (CSED).
\end{abstract}

Methodology: We apply the meta-analysis technique developed by Hunter, Schmidt and Jackson (1982) and Hunter and Schmidt (2000) for a sample of 48 published studies over the period of the last twenty years.

Findings: We find that masculinity, individualism and long term orientation moderate the association between profitability and CSED. Given the weight of US studies on the overall sample, we conduct a sensitivity analysis to examine how this factor may affect the findings. After excluding these studies, only long term orientation and individualism remain strong moderators of the association between profitability and CSED.

Originality/value: Our study provides further evidence on the impact of institutional frameworks on CSED. It has, also, policy implications for managers of multinational corporations.

Key words: Corporate social and environmental disclosure (CSED); Profitability; Cultural dimensions; Meta-analysis.

\title{
The effect of national culture on the association between profitability and corporate social and environmental disclosure: a meta-analysis
}

\section{Introduction}

In recent years, corporate social and environmental disclosure (hereafter referred to as CSED) has become a central theme of debate amongst several economic actors. Richardson, Welker and Hutchinson (1999, p. 17) defined corporate social and environmental behaviours as "discretionary actions undertaken by companies intended to advance social and environmental issues". During the last decade, environmental, social information has been 
gaining momentum in accounting disclosure literature (Cormier, Magnan, and Van Velthoven, 2005; Branco and Rodrigues, 2008; Reverte, 2009; Siregar and Bachtiar, 2010).

Recent literature related to the determinants of CSED (Chih, Chih and Chen, 2010; Williams and Zinkin, 2008) called for more cross-national studies to explore the effect of cultural dimensions on CSED. Using a cross-national sample, Orji (2010) examined the relationship between cultural dimensions and CSED. Accordingly, we extend his study by considering the moderating effect of cultural dimensions on the association between corporate performance and CSED.

Our work is motivated by the recent review on the determinants of CSED by Fifka (2013). ${ }^{1}$ Fifka (2013, p. 25) suggests that "only for the relation between financial performance and reporting are conclusions more difficult since only slightly over half of all studies, $56 \%$ have found a positive correlation". Similarly, Guidry and Patten (2012) review the literature dealing with financial control variables for CSED. They note that corporate performance was most often used as a control variable for CSED and results are mixed. Similarly, Lee and Hutchison (2005) note also the inconclusive empirical evidence concerning the same relationship. They argue that (p. 99) this inconsistency across previous empirical findings "leaves the role of profitability in environmental disclosure incompletely explained". Accordingly, in the present paper we focus our meta-analysis on profitability as an explanatory variable of CSED because of the mixed evidence provided in social and environmental disclosure literature (Hackston and Milne, 1996; Branco and Rodriguez, 2008) $)^{2}$. Our work complements Orlitzky, Schmidt and Rynes (2003) by being the first to use

\footnotetext{
1 Previous meta-analyses, dealing with the effect of corporate characteristics on voluntary disclosure, have excluded particular aspects of disclosure especially CSED. For instance, Ahmed and Courtis (1999, p. 43) suggested that their metaanalysis "excluded those that examined only a particular disclosure aspect, for example..... environment and social disclosure". Similarly, Khlif and Souissi (2010) focused on financial and non-financial information dealing with strategic and forward-looking information.

2 In their empirical analysis, Branco and Rodriguez (2008) state that "In view of the existence of these results and different interpretations, the association between this variable and SRD is tested without making any a priori assumption about the sign of such association".
} 
the meta-analysis technique to examine the impact of cultural dimensions on the association between profitability and CSED. Lee and Hutchison (2005) argue that culture factors play a critical in the decision to disclosure environmental information. They call for more future investigation of the effect of culture on CSED across national boundaries.

The meta-analysis technique constitutes a statistic tool which enables researchers to overcome the limitations of any narrative review and summarises a large collection of results in a statistic systematic manner (Ahmed and Courtis, 1999). According to Lipsey and Wilson (2001) meta-analysis can make significant contributions to general knowledge by developing a robust framework of the whole body of research on a given topic. It allows a cross-national investigation of a specific topic.

Cross-cultural research suggests that culture can influence leadership concepts and behaviour (House, Wright and Aditya, 1997). However there is no solid empirical evidence that examines this topic. For instance, Ringov and Zollo (2007, p. 476) suggest that "unfortunately, as of today, we do not have a solid empirical base to link national culture to corporate responsibility, most of the debate being fueled by conceptual arguments or anecdotal evidence from cross-country case studies". Therefore, our meta-analysis attempts to fill the gap and tests for the moderating effects of national culture on the association between corporate profitability and CSED. To the best of our knowledge, by integrating cultural dimensions as moderating variables, this is the first meta-analysis devoted specifically to examining the effect of profitability on CSED.

Ullmann (1985) suggests that society-related determinants, like culture, are crucial in explaining CSED. In the same vein, Van der Laan Smith et al. (2005, p. 125) posit that "For preparers (i.e. companies) it is important to understand the differential pressures for CSD in different countries in order to condition their CSD disclosure strategy accordingly as they enter foreign markets". Therefore, understanding the effect of national culture on CSED will 
benefit managers of multinational firms when implementing social and environmental strategies in foreign markets to reduce public scrutiny and legitimacy gap.

In our meta-analysis, we consider three culture dimensions including masculinity; individualism; and long term orientation. We find that the association between profitability and CSED is moderated by masculinity, individualism and long term orientation. In this regard, in settings characterised by low (high) individualism, low (high) masculinity and high (low) long term orientation there is a significant (non-significant) association significant between corporate profitability and CSED. Given the weight of US studies on the overall sample, we conduct a sensitivity analysis to examine how this factor may affect the findings. After excluding these studies, only long term orientation and individualism remain strong moderators of the association between profitability and CSED.

Our paper contributes to the literature as follows. On the one hand, it represents an extension of previous meta-analysis studies related to voluntary disclosure (Fifka, 2013; Ahmed and Courtis, 1999; Khlif and Souissi, 2010) by focusing only on CSED. On the other hand, this meta-analysis may inform multinational companies since cultural-specificity will require high investments in understanding and implementing decisions and strategies rather than in adopting a standard approach applicable in all cultural settings.

The rest of the paper is structured as follows. In section 2, we present the theoretical framework linking CSED to profitability and we develop the hypotheses. Section 3 describes the data and their characteristics. Section 4 presents the meta-analysis technique and the methodology used in this paper. Section 5 reports the results. Finally, section 6 concludes.

\section{Literature review}

\section{1. Theoretical framework}

Corporate financial profitability is viewed as a key factor that can influence CSED. For instance, Hackston and Milne (1996) suggest that profitability is the factor that allows 
management the freedom and the flexibility to undertake and reveal to stakeholders more extensive social and environmental actions. Similarly, Roberts (1992) posits that in periods of low financial profitability, priority is given to economic demands over discretionary social and environmental responsibility expenditures. Operating under satisfactory financial performance has a definite effect on the level of commitments of top corporate management towards future social and environmental responsibility actions (Ullmann, 1985). Empirical literature dealing with the determinants of CSED generally predicts a positive and significant association between profitability and CSED based on three theoretical frameworks including stakeholders, legitimacy and proprietary costs theories.

Stakeholder theory suggests that companies try to manage their relationships with different stakeholders (e.g. employees, consumers) in order to gain competitive advantages. This should lead to an improvement in the financial performance. Profitable firms have the duties to contribute to the welfare of different stakeholders interacting with them. Therefore, high disclosure quality represents a positive response to social pressure and the self-regulation mechanism undertaken by the firm (Naser et al., 2006). Firms, which achieve a good performance, are more exposed to public pressures and scrutiny. Consequently, they try to increase CSED in order to gain more legitimacy in the eyes of several stakeholders including customers, employees and social and environmental organizations

Legitimacy theory suggests that companies try to seek an approval of their activity from the society in which they operates (Branco and Rodriguez, 2008). Firms realising high profitability are subject to more political visibility and public scrutiny. Therefore, making CSED is regarded as a crucial tool used by managers to send a legitimacy signal, decrease public scrutiny and reduce the legitimacy gap between company and its stakeholders (Naser et al., 2006). 
Finally, proprietary costs theory suggests that poor financial conditions reduce the firms' abilities to withstand stakeholders' pressures. In a corporation with low economic performance and fewer economic resources, management places more emphasis on activities which have a more direct effect on the corporation's earnings and profitability than in disclosing CSE information (Ullman, 1985; Roberts, 1992). According to Cormier and Magnan (2003: 49) "The ability of a firm to incur proprietary costs as a result of its environmental reporting strategy is dependent upon its financial condition. Hence, it appears that only firms that are financially sound may be able to trade off the benefits from additional environmental disclosure with the costs of revealing potentially damaging information with respect to their environmental performance".

Based on the theoretical frameworks presented above, we formulate that:

Ho: there is a positive association between profitability and CSED.

\subsection{The effect of cultural dimensions on the association between profitability and CSED}

Hofstede (1984: 23) defines culture as "the collective programming of the mind which distinguishes the members of one human group from another". He identify five cultural dimensions including individualism; masculinity and long term orientation. Culture has been hypothesized to affect financial disclosure (Hope, 2003; Hussein, 1996). Orij (2010) uses cultural dimensions to explain the variability in social and environmental practices. More recently, Jia, Van Lent and Zeng (2014) examine the effect of masculinity on financial misreporting. This stream of accounting research suggests that culture may play a critical role in determining management behaviour with respect to financial and non-financial reporting. Cross-cultural research suggests that culture can influence leadership concepts (House, Wright, \& Aditya, 1997). Ringov and Zollo (2007, 467) state that "concept of corporate responsibility is inherently context-specific, with national culture playing an important part in influencing how society expects businesses to behave". Stulz and Williamson (2003) suggest 
that culture affects how resources were allocated. Goodenough (1970) posits that the relationship of an economic state of affairs to a social one was often largely or entirely affected by human action which was guided, also, by the cultures of the actors. In same vain, Schneider and DeMeyer (1991) and Luthans, Welsh and Rosenkrantz, (1993) suggest that national culture orientations influence leadership styles and the way of resources management. Firm's business culture generally affects the way of resources (e.g. profits) allocation and depends on management cultural orientations (Tsoutsoura, 2004). This is particularly true when a firm is characterised by good financial performance and management may have to choose between implementing corporate social and environmental actions and satisfying stakeholders' needs or focusing on wealth maximization of shareholders as a sole goal of a corporation (Tsoutsoura, 2004). In this regard, Vitell, Nwachukwu and Barnes, (1993) suggest that cultural norms may affect management moral philosophy and thus ethical decision-making.

The above discussion implies that national culture is a decisive factor in shaping management behaviour with respect to financial resources allocation and thus social and environmental responsibility. Thus we expect that cultural dimensions may moderate the effect of profitability on CSED.

We focus on three cultural dimensions namely individualism, masculinity and long term orientation $^{3}$ since they are more linked to social and environmental behaviour (Orji, 2010). In the same vein, Vitell et al. (1993) state that cultural values play an important role in shaping individual behaviour with respect to the ethical decision making within a business context.

\footnotetext{
${ }^{3}$ Other cultural dimensions exist which are uncertainty avoidance and power distance. We do not consider them since uncertainty avoidance is more linked to risk and financial disclosure (Khlif and Hussainey, 2014), while power distance deals more with hierarchical concerns inside the company. In addition, for these two cultural dimensions, Orij (2010) provides empirical evidence that uncertainty avoidance and power distance are less linked to CSED compared to individualism, masculinity and long term orientation (for more details, see table 3, p. 878 in Orij, 2010).
} 
This implies cultural values may influence the way of firm's resources are allocated and the manner that firm shares its financial profitability with stakeholders.

\section{(i) Individualism}

Individualism measures the degree of integration between members of a society (Hope, 2003). Everyone is expected to prioritise himself/ herself or his/her immediate family (Hussein, 1996). In highly individualistic societies, firm's management may demonstrate less concern about the broader impact of business on society and focus more in maximizing their own compensations and investors' needs (Ringov and Zollo, 2007). According to Vitell et al. (1993), persons operating in high "individualist" societies, will be more concerned with their own self interest and tend to be less influenced by group norms.

By contrast, collectivism pertains to societies where people are integrated strongly in groups which protect their interests. In collectivist societies, people have to show strong loyalty (Hope, 2003). According to Hussein (1996: 99) “individualist societies will be geared to individual users while in collectivist societies it will be geared to institutional needs". Vitell et al. (1993) suggest that persons operating in high collectivist societies can not distance themselves from various groups to which they belong (employees, customers, shareholders, business group) and expect in turn permanent loyalty. This implies that, in collectivist societies, managers deal more with stakeholders' needs, whilst, in individualist societies, companies consider only investors' interests. Therefore, management operating in low individualist society will devote more effort to support sustainability actions especially when it has sufficient financial resources generated by good financial performance. Accordingly, it is expected that, in collectivist societies, profitability has a more significant effect on CSED. Thus, the following hypothesis is tested:

$H_{1}$ : There is a significant positive (non-significant) association between profitability and CSED in settings characterized by low (high) individualism. 


\section{(ii)Masculinity/femininity}

Masculine culture puts more emphasis on economic growth and it is less related to social and environmental orientations (Hofstede, 2001; Hussein, 1996; Orji, 2010). Jia et al. (2014) posit that masculinity is characterised by a complex of masculine behaviours including aggression and egocentrism. Highly masculine societies, firm's management attributes less importance for inclusion, cooperation, and solidarity and managers focus on advancement and material success (Ringov and Zollo, 2007). For instance, Tice and Baumeister (2004) provide evidence that masculinity inhibits helping behaviours. In the same vein, Vitell et al. (1993, p. 758) state that "societies that are characterized as masculine encourage individuals, especially males, to be ambitious, competitive and to strive for material success. These factors may contribute significantly to one's engagement in unethical behaviour".

By contrast, feminine society is more oriented towards social equality and solidarity (Hussein, 1996). In feminine society, people tend to emphasize on the quality of the "whole" life rather than money (Dartey-Baah, 2013). Accordingly, especially when they achieve good performances, it is expected that companies, operating in feminine societies, communicate more CSED in order to be in line with stakeholders' expectations. Thus, the following hypothesis is formulated:

$\mathrm{H}_{2}$ : There is a significant positive (non-significant) association between profitability and CSED in settings characterised by high (low) femininity.

\section{(iii) Long term orientation}

This dimension captures the perspectives of a person to the time dimension of decisions (Salter, Sharp and Chen, 2013). Long term orientation refers to the fact that, in both the short and long term horizons, companies want to preserve their good performances (Hussein, 1996). This implies that in the long term orientation culture, managers need to establish good relationships with their stakeholders including customers, employees, social and 
environmental organisations and investors. These good relationships between company and its stakeholders imply more products' acceptance among consumers and more motivations among employees which translate into more productivity and thus higher financial performance. Firms operating in high long term orientation countries need to be in line with social and environmental norms to preserve their reputation among stakeholders and build long term and strategic competitive advantages (Orji, 2010). This is particularly true when companies realise good performances and implies more capability to spend financial resources in social and environmental issues and to disclose information about them to build strong ties with diverse stakeholders. Therefore, it is expected that, for companies operating in countries with high long term orientation perspectives, corporate profitability has a significant positive effect on CSED. Thus, we formulate the following hypothesis:

H3: There is a significant positive (non-significant) association between profitability and CSED in settings characterised by high (low) long term orientations.

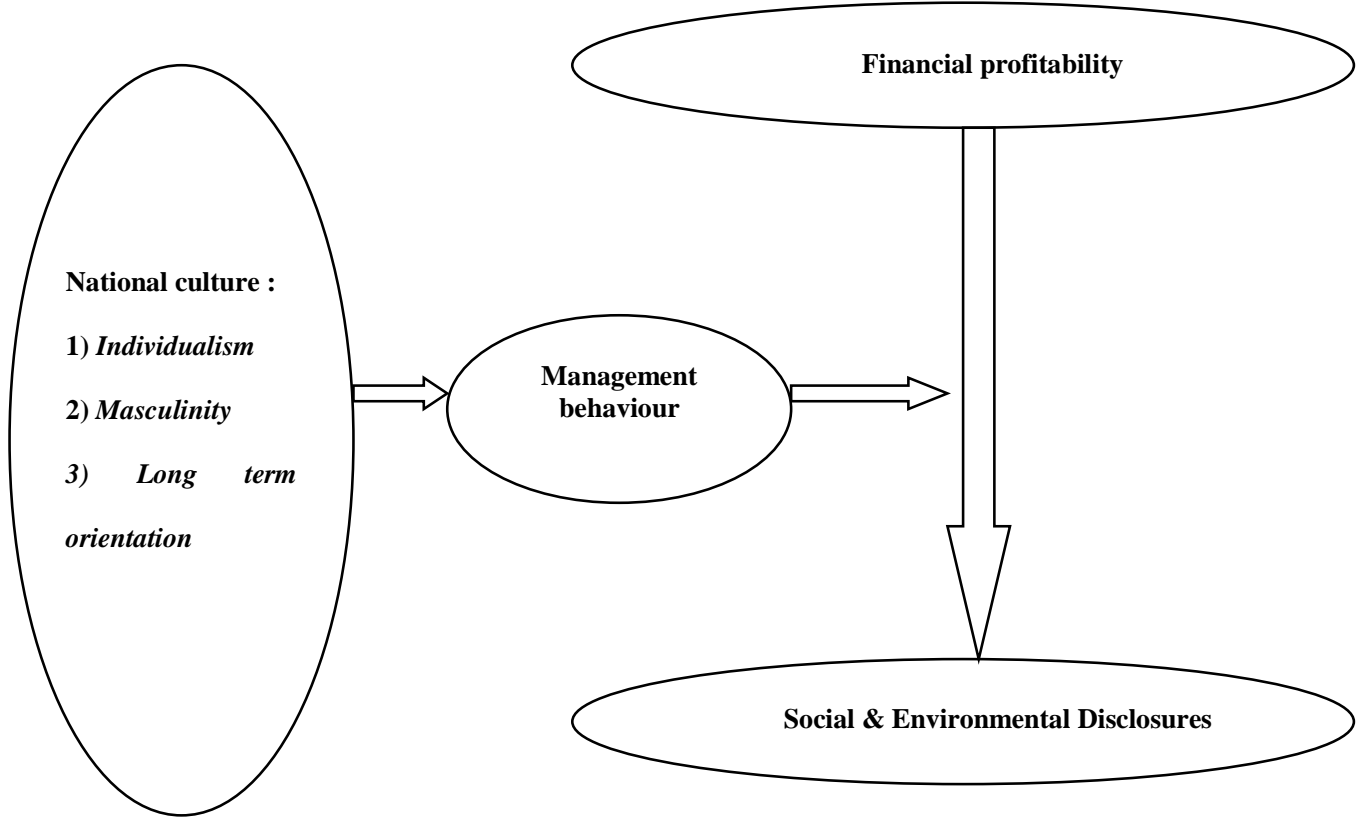

Figure 1. Conceptual framework 


\section{Sample of studies included in the meta-analysis}

Since the pioneering work of Moskowitz (1972) dealing with CSED and corporate performance, the determinants of CSED empirical literature has proliferated. According to Fifka (2013), during the 1970s and 1980s empirical studies mostly originated from North American countries (e.g. USA and Canada) and Western European countries (e.g. UK, Germany). During the last two decades, several empirical enquiries have been conducted to examine the determinants of CSED in developing and emerging economies. Accordingly, we choose a large period of investigation spanning from 1972 to 2013 to reduce the bias of omitted studies in our meta- analysis. The main topics of the selected papers were the determinants of $\mathrm{CSED}^{4}$. Keywords, used in the database search and which included “determinants of CSED”, “ factors influencing CSED” and "the association between financial performance and CSED”, were taken from different editorial sources such as Science Direct; EJSEbsco; Blackwell; Springer; Emerald; ABI Inform; and SSRN,. We consult specialised journals including Accounting; Organization and Society; Accounting; Accountability; Auditing Journal; Corporate Social Responsibility and Environmental Management; and Journal of Business Ethics. The main criterion, used to include a study in the meta-analysis, is that financial performance is examined as an explanatory or control variable. Given this criterion, we exclude several studies if they do not include financial performance when explaining the variation of CSED. In addition, we exclude all studies which provided only descriptive statistics. Finally, we exclude all studies examining more than one setting since our objective is to test the effect of country's culture dimensions score on the association between corporate performance and CSED. Based on these criteria, our final sample

\footnotetext{
${ }^{4}$ To try to get the maximum number of papers, we consult the two meta-analyses conducted by (Orlitzkyet al, 2003) and Fika (2013) (for more details see: table 1 from page 6 to page 14 for Fifka (2013) and appendix A from page 428 to page 432 for Orlitzky et al,, 2003).
} 
encompasses 48 empirical studies yielding 49 independent samples ${ }^{5}$. Table 1 provides more information about the sample selection process.

\section{Insert table 1 about here}

Table 2 presents detailed information about each study including the year of publication; reporting years; country; scores for cultural dimensions; proxies used to measure financial performance; and the Pearson coefficient of correlation between profitability and CSED.

\section{Insert table 2 about here}

${ }^{5}$ Since Chau and Gray (2002) separately consider two settings in their empirical enquiries (Hong Kong and Singapore). 


\section{Meta-analysis technique}

In accounting and finance literature, a crucial research question is how to reconcile conflicting findings. The meta-analysis technique represents a statistical systematic tool which combines the results of several studies that address a set of related research topics. It constitutes, also, an attempt to overcome the problem of reduced statistical power in studies with small sample sizes and allows for more accurate data analysis. In our paper, we use the meta-analysis technique, developed by Hunter, Schmidt, and Jackson (1982) and Hunter and Schmidt (2000), in order to draw logical conclusions from papers, related to the determinants of CSED, which were undertaken over the last thirty years. According to Glass (1976) metaanalysis is the statistical analysis of a large set of mixed findings in order to reconcile contradictory results and to draw logical conclusions.

\subsection{Effect size}

The meta-analysis technique requires the use of the effect size to measure the magnitude of the association between the dependent variable (CSED) and corporate profitability. In studies where the coefficient of correlation $r$ is reported, such a statistical tool is used to measure the effect size. When only the t-statistic or Z-statistic results are reported, $r$ is computed as $\sqrt{\frac{t^{2}}{\left(t^{2}+d f\right)}} \quad 6$ or $\frac{Z}{\sqrt{N}}$.

According to Hunter and Schmidt (2000), three steps should be followed to determine the mean correlation $(\bar{r})$ and the estimate of the population variance. These are as follows.

(i) Firstly, the mean correlation $(\bar{r})$ is computed as:

$$
\bar{r}=\frac{\sum\left(r_{i} \cdot N_{i}\right)}{\sum N_{i}}
$$

\footnotetext{
6 This formula generates positive numbers. According to Green (2008, cf. Chapter 3), if the regression coefficient is negative, it is necessary to convert the effect size to a negative number.
} 
$N_{i}$ : Sample size for study $i$

$r_{i}$ : Pearson correlation coefficient for study $i$.

(ii) Secondly, the observed variance $\left(S_{r}^{2}\right)$ and the sampling error variance $\left(S_{e}^{2}\right)$ are calculated using the following formulas:

$$
\begin{aligned}
& S_{r}^{2}=\frac{\sum N_{i}\left(r_{i}-\bar{r}\right)^{2}}{\sum N_{i}} \\
& S_{e}^{2}=\frac{\left(1-\bar{r}^{2}\right)^{2} K}{\sum N_{i}}
\end{aligned}
$$

Whereby $K$ is the number of individual studies included in the meta-analysis.

(iii) Finally, the variance, used to estimate a confidence interval, is $\left(S_{r}^{2} / K\right)$.

Normally, the estimates of population mean $(\bar{r})$ and the standard deviation $\sqrt{S_{r}^{2} / K}$ are used to construct a 95 per cent confidence interval. In addition, the Z-statistic, computed as $\left(\frac{\bar{r}}{\sqrt{S_{r}^{2} / K}}\right)$, is used, also, to assess the significance of the relationship between the dependent and explanatory variables.

To test for moderating effects, a chi-square statistic test is suggested to determine whether the observed variance is trivial or higher than expected (heterogeneous) (Ahmed \& Courtis, 1999).

$$
\chi_{K-1}^{2}=\frac{N S_{r}^{2}}{\left(1-\bar{r}^{2}\right)^{2}}
$$

The homogeneity test is developed to determine whether the likelihood of variance amongst the effect sizes is due only to sampling error. If the chi-square statistic is deemed to be significant for a group of studies, a procedure, analogous to analysis of variance, can be used. Studies are divided repeatedly into subgroups according to study features until the withingroup variation is non-significant or until all of moderating variables have been considered. 


\subsection{Moderating factors}

In order to test the moderating effect of the three cultural dimensions (individualism; masculinity; and long term orientation) on the relationship between financial performance and corporate profitability, we compute the median for each dimension. We classify a cultural dimension as high (low) if the country's score is superior (inferior or equal) to the median. With respect to the three cultural dimensions, we obtained each country's score from the following website (http://geert-hofstede.com/countries.html). In this study, we use the scores for each country for the three culture dimensions identified by Hofstede including individualism; masculinity; and long term orientation. This approach has been also applied in other empirical studies including Orij (2010), Hope (2003), and Hope, Kang, Thomas and Yoo (2008). Baskerville (2003) criticizes the approach adopted by Hofstede to measure culture. She suggests that anthropology and sociology reject of the theoretical basis for Hofstede's approach. She adds that the variables used to proxy for the five dimensions are more connected with socio-economic aspects rather than culture. In his response to these criticisms, Hofstede (2003) states clearly that the arguments advanced by Baskerville (2003) are "largely irrelevant to cross-cultural accounting research" (p. 811). Similarly, Minkov and Hofstede (2011, p. 10), suggest that "the key strength of Hofstede's work has been its ability to adapt and remain progressive".

It should be noted here that restricting to only cultural dimensions may be criticisable since other factors that may intervene on the association between profitability and social and environmental disclosure such as country's sustainability level, the level of legal enforcement, stakeholders' power and economic development. Furthermore, the use of different measures of profitability over a period of thirty years characterised accounting reforms dealing with revenues and expenses recognition may also introduce a bias into the results since 
profitability proxy is influenced the accounting principles used to compute firms' earnings during this period.

\subsection{Additional and sensitivity meta-analytic analysis ${ }^{7}$}

The first sensitivity analysis takes into account the weight of US studies in our analysis. For instance our sample encompasses 12 studies conducted in USA that represent $(12 / 49=24.489$ $\%$ of the overall sample). Given this important weight, we try to test the same hypotheses by excluding US setting from the analysis.

The second test represents a classic test in meta-analytic literature since we study whether the proxy, used to measure profitability, affects the association between profitability and CSED (Ahmed and Courtis, 1999). Accordingly, profitability is divided into three groups: net profit/equity (ROE); net profit/total assets (ROA); and net profit/total sales (ROS).

The third test consists of examining how a period of time affects the examined relationship (Ahmed and Courtis, 1999). This test is performed given the increased awareness on CSED due to the emergence of several social and environmental organizations (e.g. green funds) (Richardson and Welker, 2001). Therefore, we divide our meta-analytic sample into two groups: pre-2000; and post-2000 including 2000. We excluded studies with samples spanning from the pre-2000 period to the post-2000 period (e.g. of Pahuja, 2009).

The fourth classic meta-analytic test consists of examining the effect of the publication quality on the relationship between profitability and CSED. Meta-analysis may be affected by the publication bias (Moller and Jennions, 2001). Generally, quality journals prefer to publish papers with significant results since editors do not like 'no results' papers. Therefore, we divide our overall sample into two groups, namely, quality journals studies and low quality journals papers. The first group includes all published papers which appear in journals ranked

\footnotetext{
${ }^{7}$ In the studies included in our meta-analysis, disclosure index is constructed using a number of items dealing with social and environmental concerns. The content analysis approach is applied to determine CSED score. Only, in Toms (2002), a dummy variable is used to proxy for CSED disclosure. Given the lack of divergence between studies in measuring CSED, we don't control for this issue.
} 
as $A^{*}$ and $A$ by Australian Business Dean Council (ABDC) journal ranking in 2013. The second group includes all identified studies published in other journals.

Finally, we assess the stability of results by testing for publication bias. Stanley (2005) suggests that publication bias, or the 'file drawer problem', has long been a major concern to meta-analysts. According to Hay, Knechel and Wong (2006), including only published studies increases the quality of meta-analytic results but it has potential weaknesses since it does not account for unpublished studies either in a journal or in SSRN that are not available for accumulation in the meta-analysis. Rosenthal (1979) refers to this problem as the 'file drawer problem'. We apply Orwin's (1983) method to show the number of studies failing to report significant results that would be needed to reverse a significant association. This method requires the estimation of the fail-safe $\mathrm{N}$ being the number of unreported studies with insignificant results which are required to reduce the mean effect size to a specified criterion ${ }^{8}$. The fail-safe $\mathrm{N}$ is calculated using equation (5).

$$
K_{0}=K\left[\frac{E S_{k}}{E S_{0}}-1\right] \text {. }
$$

$K_{0} \quad$ Fail-safe $\mathrm{N}$ or the number of non -significant, unpublished studies

$K \quad$ Number of studies included in the meta-analysis

$E S_{k} \quad$ Effect size of studies included in the analysis

$E S_{0} \quad$ The criterion effect size of 0.05 significance level which will reduce the effect size to a specified criterion.

\section{Results}

\subsection{The moderating effect of cultural dimensions on the association between profitability and CSED}

Table 3 presents the results for the overall sample and, then, for each cultural dimension. For the overall sample, the profitability variable has a mean correlation of $0.072(\mathrm{Z}=3.619)$ with a 95 per cent confidence interval between 0.033 and 0.112 . These statistics indicate that there

\footnotetext{
${ }^{8}$ In meta-analytic accounting research, two main approaches were used to compute the fail safe-N: (i) Orwin's (1983) method and (ii) Rosenthal's (1991) approach. The first approach has been used in meta-analytic accounting research when authors use Hunter and Schmidt's (2000) approach (e.g. Ahmed, Chalmers and Khlif, 2013; García-Meca and Sánchez-Ballesta, 2010; Khlif and Hussainey, 2014), while the second has been applied under Stouffer combined test (Hay et al., 2006; Lin and Hwang, 2010). Since our meta-analysis is based on Hunter and Schmidt's (2000) approach, we follow the same methodology used to compute the fail safe-N in prior meta-analytic accounting research.
} 
is a significant relationship between voluntary disclosure and profitability. Thus, $\mathrm{H}_{0}$ is supported and the meta-analytic results confirm that there is a positive association between profitability and CSED. However, the computed chi-square statistic accounts for 180.557 and it is significant at 1 per cent significance level. This indicates the need to undertake further analysis to reduce heterogeneity and tests for the moderating effects of cultural dimensions (individualism, masculinity and long term orientation).

Findings show that individualism moderates the association between profitability and CSED since the association is significant only for countries classified in the low individualism group with a mean correlation of $0.145(Z=5.066)$, whilst it is non-significant for high individualist countries with a mean correlation of $0.012(\mathrm{Z}=0.538)$. Therefore, hypothesis $\mathrm{H}_{1}$ is accepted. Companies realising good financial performance in low individualist countries share their profits with all stakeholders by undertaking social and environmental actions and disclose information about them to increase their legitimacy. This means that, in collectivist societies, managers will spend money to deal with stakeholders' needs, whilst, in individualist societies, companies consider only investors' interests.

Masculinity affects the relationship between profitability and CSED since the association is non-significant for high masculinity countries $(0.045 ; \mathrm{Z}=1.717)$ and significant for low masculinity settings $(0.105 ; \mathrm{Z}=3.577)$. Therefore, hypothesis $\mathrm{H}_{2}$ is accepted. These findings are in line with those reported by Tice and Baumeister (2004) and confirm that high masculinity inhibits helping behaviours. In highly masculine societies, management will put more emphasis on their own material success and investors' needs when realising good financial performance. By contrast, in feminine society (low masculinity), management will be more oriented towards social equality and solidarity to satisfy all stakeholders' needs and signal its legitimacy by undertaking social and environmental actions and communicate information about them under high financial profitability. 
Finally, the long term orientation cultural dimension exerts a significant effect on the relationship between profitability and CSED since, with a mean correlation of $0.118(\mathrm{Z}=$ 3.702), the association is significant in settings characterised by high long term orientation, whilst it not significant for low long term orientation countries with a mean correlation of $0.019(\mathrm{Z}=0.700)$. Therefore, hypothesis $\mathrm{H}_{3}$ is accepted. This result implies that profitable companies, operating in long term orientation settings, try to build long term relationship with stakeholders (employees, customers, social and environmental organizations) by undertaking more social and environmental actions and that, in order to increase their long term performance, they disclose information to signal their legitimacy and to preserve strong ties with their stakeholders.

\section{Insert table 3 about here}

\subsection{Additional and sensitivity meta-analytic analysis}

Table 4.A presents the results without the effect of US studies. After excluding US studies for the analysis, long term orientation and individualism moderate the association between CSED and profitability. For instance, the relationship between profitability and CSED is only significant for high long term orientation settings with a mean correlation of $0.164(\mathrm{Z}=$ 4.343), while it is not significant for low long term orientation countries $(0.038 ; \mathrm{Z}=1.317)$. Similarly, low individualist settings show a significant positive association between profitability and CSED $(0.158 ; Z=4.645)$, while it is not significant for high individualism countries $(0.037 ; Z=1.701)^{9}$.

Contrary to the results generated for the overall meta-analytic sample, the association between profitability and CSED is not moderated by masculinity when we exclude the US setting from the analysis. Therefore, the sensitivity analysis confirms the moderating effect of individualism and long term orientation on the association between profitability and CSED.

\footnotetext{
${ }^{9}$ The confidence interval ranges from -0.005 to 0.079 .
} 
In the second sensitivity test (Table 4.B), we examine how the proxy used to measure profitability affects the examined relationship. As shown in Table 4, the association remains significant regardless of the proxy used to measure profitability (ROE, ROA, ROS).

The third sensitivity test examines how the time period affects the association between profitability and CSED. Our results show that the relationship is negative and non-significant for the pre-2000 period with a mean correlation of $0.006(Z=0.232)$, whilst it significant for the post-2000 period with a mean correlation $0.112(Z=4.254)$. This confirms that the increased awareness about CSE actions and the emergence of several social and environmental organizations during the last decade have contributed to the improvement of CSED especially when firms realize good financial performance.

The fourth classic meta-analytic test consists of examining the effect of the quality of publication on the relationship between profitability and CSED. Our results show that the association is significant only for quality journals with a mean correlation of $0.083(\mathrm{Z}=$ 3.520), whilst it is non-significant for low quality journals with a mean correlation of 0.052 ( $\mathrm{Z}$ $=1.486$ ).

Finally, we test for the stability of the obtained results by using the fail-safe for each reported significant association. The fail-safe $\mathrm{N}$, computed in tables 4 (A \& B), show that the reported significant associations do not suffer from a file-drawer problem given the large number of unreported studies with insignificant results required to reduce the mean effect size to a specified criterion. For instance, in table 4, the fail-safe $\mathrm{N}$ ranges from 34 for long term orientation to 69 for the overall meta-analysis. By contrast, in tables 5.A and table.5.B, the fail-safe Ns computed for significant associations indicate a lower stability of the metaanalytic results compared to findings reported in table 4 since the numbers of unreported studies that would be required to change the results are not really large.

\section{Insert table 4 about here}




\section{Conclusion}

The association between profitability and CSED was very controversial in social and environmental disclosure literature (Branco and Rodriguez, 2008; Fifka, 2013). Accordingly, we apply a meta-analysis to integrate the results; to detect the causes of the variability of results across studies; and to draw conclusions. More specifically, we explore the moderating effects of cultural dimensions on the association between profitability and CSED.

Our findings show that individualism, masculinity and long term orientation moderate the relationship between profitability and CSED. For instance, companies, operating in settings characterized by low individualism, low masculinity or high long term orientation, are more likely to disclose more CSED when they realize good financial performance. When excluding US studies from the analysis, only individualism and long term orientation remain strong moderators of the association between profitability and CSED.

Our meta-analytic findings add to the extant literature on the determinants of CSED by focusing on the moderating effects of three cultural dimensions on the association between profitability and CSED. They highlight the importance of culture when one analyses CSED practices. They provide, also, evidence that the applicability of stakeholder and legitimacy theories is linked to the cultural values prevailing in one country. Our findings can help, also, regulators and policy makers who have to take into account cultural dimensions characteristics when adopting new legislations and making reforms dealing with social and environmental laws. Meta-analytic results are useful, also, to the managers of multinational corporations, when preparing social and environmental reports. Managers need to consider the national cultures and the social orientation of countries in relation with the level of social and environmental information disclosed when achieving good financial performance.

This meta-analysis has a number of limitations. For instance, our study does not take into account the problem of endogeneity between profitability and CSED. However, since the 
primary data in the collected studies do not control for this problem, we are unable to control for endogeneity in our statistical analysis. In addition, this study focuses only on cultural dimensions without taking into account other factors that may also affect the association between profitability and social and environmental disclosure such as country's sustainability level, the level of legal enforcement, stakeholders' power and economic development. Furthermore, the use of different measures of profitability over a period of thirty years may bias the results given the fact that several accounting reforms have been undertaken which may influence the accounting principles used to compute firm's profitability during this period. Finally, the cultural dimensions developed by Hofsede may receive several critics since they relate more to investors' perceptions and they do not take into account the possibility of coexistence of several cultural orientations in companies such multinationals.

Further meta-analysis can examine, also, the moderating effect of cultural and political dimensions on the relationship between specific ownership attributes (ownership concentration; foreign ownership) and social and environmental reporting practices. In addition, Al-Tuwaijri et al. (2004) suggest that endogeneity represents a serious problem in CSED and corporate performance relationship. However, the majority of empirical studies do not control for this issue. Accordingly, future empirical investigations have to take into account the simultaneous associations between CSED and corporate performance. Finally, since meta-analysis cannot be exhaustive in collecting studies, future research may build on our meta-analytic work and re-examine the same question when more empirical papers dealing with the determinants of CSED are available to assess the stability of the results found. 


\section{References}

*Studies included in the meta-analysis

*Ahmad, Z., Hassan, S. and Mohammad J. (2003), "Determinants of environmental reporting in Malaysia". International Journal of Business Studies, Vol. 11 No. 1, pp. 69-90.

Ahmed, K. and Courtis, J. K. (1999), “Associations between corporate characteristics and disclosure levels in annual reports: a meta-analysis", The British Accounting Review, Vol. 31 No. 1, pp. 35-61.

Ahmed, K., Chalmers, K. and Khlif, H. (2013), "A meta-analysis of IFRS adoption effects”, International Journal of Accounting, Vol. 48 No. 2, pp. 173-217.

*Alnajjar F K. (2000), "Determinants of social responsibility disclosures of U.S. Fortune 500 firms: An application of content analysis". Advances in Environmental Accounting \& Management 1 Emerald Group Publishing Limited: Bingley: 163-200.

*Al-Tuwaijri, S. A., Christensen, T. E. and Hughes, K. E. (2004), "The relations among environmental disclosure, environmental performance, and economic performance: a simultaneous equations approach", Accounting, Organizations and Society, Vol. 29 No. (5 \& 6), pp. 447- 471 .

Antonites, E. and De Villiers, C.J. (2003), "Trends in South African corporate environmental reporting: A research note", Meditari Accountancy Research, Vol. 11 No. 1, pp.1 - 10.

Baskerville, R. F. (2003), "Hofstede never studied culture", Accounting, Organizations and Society, Vol. 28 No. 1, pp. 1-14.

*Bewley, K. and Li, Y. (2000), "Disclosure of environmental information by Canadian manufacturing companies: A voluntary disclosure perspective", Advances in Environmental Accounting and Management, Vol. 1, pp. 201-236.

*Branco, M. C. and Rodríguez, L. L. (2008), "Factors influencing social responsibility disclosure by Portuguese Companies", Journal of Business Ethics, Vol. 84, pp. 497-527.

*Chau, K. and Gray, S. J. (2002), "Ownership structure and corporate voluntary disclosure in Hong Kong and Singapore”, The International Journal of Accounting, Vol. 37, pp. 247-365.

*Cho, C. H., Freedman, M. and Patten, D. M. (2012), "Corporate disclosure of environmental capital expenditures: A test of alternative theories", Accounting, Auditing and Accountability Journal, Vol. 25 No. 3, pp. 486-507.

Chih, H. L., Chih, H. H. and Chen, P. (2010), "On the determinants of corporate social responsibility: International evidence on the financial industry", Journal of Business Ethics, Vol. 93 No 1, pp. 115- 135.

*Clarkson, P., Li,Y., Richardson, G. and Vasvari F. (2008), “Revisiting the relation between 
environmental performance and environmental disclosure: an empirical analysis", Accounting, Organizations and Society, Vol. 33, pp. 303-327.

*Cormier, D. and Gordon, I. M. (2001), "An examination of social and environmental reporting strategies", Accounting, Auditing and Accountability Journal, Vol. 14 No.5, pp. 587-616.

*Cormier, D. and Magnan, M. (1999), "Corporate environmental disclosure strategies: determinants, costs and benefits", Journal of Accounting, Auditing and Finance, Vol. 14 No.3, pp. 429-451.

*Cormier, D. and Magnan, M. (2003), "Environmental reporting management: a continental European perspective", Journal of Accounting and Public Policy, Vol. 22 No.1, pp. 43-62.

*Cormier, D., Magnan, M. and Van Velthoven B. (2005), "Environmental disclosure quality in large German companies: economic incentives, public pressures or institutional conditions?" The European Accounting Review, Vol. 14 No.1, pp. 3-39.

*Cowen, S. S., Ferreri, L. B. and Parker, L. D. (1987), "The Impact of corporate characteristics on social responsibility disclosure: A typology and frequency-based analysis", Accounting, Organizations \& Society, Vol. 12 No. 2, pp. 111-122.

Dartey-Baah, K. (2013), "The cultural approach to the management of the international human resource: An analysis of Hofstede's cultural dimensions", International Journal of Business Administration, Vol. 4 No. 2, pp. 39-45.

*Da Silva Monteiro, S. M. and Aibar-Guzmán, B. (2010), "Determinants of environmental disclosure in the annual reports of large companies operating in Portugal", Corporate Social Responsibility and Environmental Management, Vol. 17, pp. 185-204.

Deegan, D. and Blomquist, C. (2006), "Stakeholder influence on corporate reporting: an exploration of the interaction between WWF-Australia and the Australian minerals industry", Accounting, Organizations and Society, Vol. 31, pp. 343-372.

De Villiers, C. J. and Barnard, P. (2000) "Environmental reporting in South Africa from 1994 to 1999: A research note", Meditari Accountancy Research, Vol. 8 No. 1, pp.15 - 23.

Di Maggio, P. J. and Powell, W.W. (1991), "The iron cage revisited: Institutional isomorphism and collective rationality in organization fields". American Sociological Review, Vol. 48, pp. 147-160.

Fifka, M, S. (2013), "Corporate responsibility reporting and its determinants in comparative perspective - a review of the empirical literature and a meta-analysis", Business Strategy and the Environment, Vol. 22, pp. 1-35.

* Freedman, M. and Jaggi, B. (1982), "Pollution disclosures, pollution performance and economic performance", Omega: The International Journal of Management Science, Vol. 10, pp. 167-176. 
* Freedman, M. and Jaggi, B. (1988), "An analysis of the association between pollution disclosure and economic performance", Accounting, Auditing and Accountability Journal, Vol. 1 No.2, pp. 43-58.

*Gamerschlag, R., Moller, K., Verbeeten, F. (2010), "Determinants of voluntary CSR disclosure: Empirical evidence from Germany", Review of Management Sciences: DOI 10.1007/s11846-010-0052-3.

Gao, S., Heravi, S. and Xiao, J. Z. (2005), "Determinants of corporate social and environmental reporting in Hong Kong: a research note", Accounting Forum, Vol. 29, pp. 233-242.

García-Meca, E. and Sánchez-Ballesta, J. P. (2010), "The association of board independence and ownership concentration with voluntary disclosure: A meta-analysis", The European Accounting Review, Vol. 19 No. 3, pp. 603-627.

*Ghazali, N. A. M. (2007), "Ownership structure and corporate social responsibility disclosure: some Malaysian evidence”, Corporate Governance, Vol. 7 No.3, pp. 251 - 266.

Glass G. 1976. Primary, secondary, and meta-analysis of results. Educational Researcher 5: 3-8.

Greene, W. H. (2008), Econometric analysis, 6th ed. London: Prentice Hall.

Guidry, R. P. and Patten, D. M. (2012), "Voluntary disclosure theory and financial control variables: An assessment of recent environmental disclosure research", Accounting Forum Vol. 36 No. 2, pp. 81-90.

*Hackston, D. and Milne, M. J. (1996), "Some determinants of social and environmental disclosures in New Zealand companies", Accounting, Auditing \& Accountability Journal, Vol. 9 No.1, pp. 77- 108.

*Hail, L. (2002), "The impact of voluntary corporate disclosure on the ex-ante cost of capital for Swiss firms", The European Accounting Review, Vol. 11 No.4, pp. 741-773.

Halme, M. and Huse, M. (1997), "The influence of corporate governance, industry and country factors on environmental reporting", Scandinavian Journal of Management, Vol. 13 No. 2, pp. 137-157.

*Haniffa, R. M. and Cooke, T. E. (2005), "The impact of culture and governance on corporate social reporting", Journal of Accounting and Public Policy, Vol. 24, pp. 391-430.

Hay, D., Knetchel, W. and Wong, N. (2006), "Audit fees: a meta-analysis of the effect of supply and demand attributes", Contemporary Accounting Research, Vol. 23 No. 1, pp. 141191.

Hofstede, G. H. (1984), "Cultural dimensions in management and planning", Asia Pacific Journal of Management, January, pp. 81-99.

Hofstede, G. H. (2001), “Culture’s Consequences”, Sage Publications, London. 
Hoftstede, G. (2003), "What is culture? A reply to Baskerville", Accounting, Organizations and Society, Vol. 28, pp. 810-813.

Hope, O-K. (2003), "Firm-level disclosures and the relative roles of culture and legal origin", Journal of International Financial Management and Accounting, Vol. 14 No.3, pp. 218-48.

Hope, O.-K., Kang, T., Thomas, W. and Yoo, Y. K. (2008), "Culture and auditor choice: a test of the secrecy hypothesis", Journal of Accounting and Public Policy, Vol. 27 No. 5, pp. 357-73.

House, R. J., Wright, N. S., \& Aditya, R. N. (1997). Cross-cultural research on organizational leadership: A critical analysis and a proposed theory. In P. C. Earley \& M. Erez (Eds.), New Perspectives in International Industrial Organizational Psychology (pp. 535-625). San Francisco: New Lexington.

Hunter, J. E. and Schmidt, F. L. (2000), "Fixed effects vs. random effects meta-analysis models: Implications for cumulative research knowledge", International Journal of Selection and Assessment, Vol. 8 No. 4, pp. 275-292.

Hunter, J.E., Schmidt, F.L. and Jackson, G.B. (1982), “ Cumulating research findings across studies”, Studying Organizations: Innovations in Methodology 4, Beverly Hill: Sage.

Hussein, M. (1996), “A comparative study of cultural influences on financial reporting in the U.S. and The Netherlands", The International Journal of Accounting, Vol. 31 No. 1, pp. 95120.

*Hussainey, K., Elsayed, M. and Abdel Razik, M. (2011), "Factors affecting corporate social responsibility in Egypt", Corporate Ownership and Control Journal, Vol. 8 No. 4, pp. 432 443.

*Jinfeng, Z. and Xue Huifeng, X. (2009), "Empirical research on factors influencing level of environmental protection information disclosure in annual reports by listed companies", Chinese Journal of Population, Resources and Environment, Vol. 7 No.1, pp. 15-22.

Jia, Y., Lent, L. V. and Zeng, Y. (2014), "Masculinity, testosterone, and financial misreporting”. Journal of Accounting Research, Vol. 52 No. 6, pp. 1195-1246.

*Khan, H. (2010), “The effect of corporate governance elements on corporate social responsibility (CSR) reporting: empirical evidence from private commercial banks of Bangladesh", International Journal of Law and Management, Vol. 52 No. 2, pp. 82- 109.

* Khan, A., Muttakin, B. M. and Siddiqui, J. (2013), "Corporate governance and corporate social responsibility disclosures: Evidence from an emerging economy", Journal of Business Ethics DOI: 10.1007/s10551-012-1336-0.

Khlif, H. and Souissi, M. (2010), "The determinants of corporate disclosure: a meta-analysis", International Journal of Accounting and Information Management, Vol. 18 No.3, pp. 198219. 
Khlif, H. and Hussainey, K. (2014), "The association between risk disclosure and firm characteristics: a meta-analysis", Journal of Risk Research, DOI: $10.1080 / 13669877.2014 .961514$.

Lee ,T. and Hutchison, P. (2005), "The decision to disclose environmental information: a research review and agenda", Advances in Accounting, Vol. 21, pp. 83-111.

*Li, W. and Zhang, R. (2010), "Corporate social responsibility, ownership structure, and political interference: evidence from China”, Journal of Business Ethics, Vol. 96, pp. 631645 .

Lin, J. and Hwang, M. (2010), "Audit quality, corporate governance, and earnings management: A Meta-Analysis". International Journal of Auditing, Vol. 14, pp. 57-77.

Lipsey, M. W. and Wilson, D. B. (2001). Practical meta-analysis. USA: Sage Publications.

*Liu, X. and Anbumozhi, V. (2009), "Determinant factors of corporate environmental information disclosure: an empirical study of Chinese listed companies", Journal of Cleaner Production, Vol. 17 No.12, pp. 593-600.

Luthans, F., Welsh, D.H. and Rosenkrantz, S.A. (1993), "What do Russian managers really do? An observational study with comparison to US managers", Journal of International Business Studies, Vol. 24 No. 4, pp. 741-762.

Maignan, I. and Ralston, D.A. (2002), "Corporate social responsibility in Europe and the U.S.: insights from businesses' self-presentations", Journal of International Business Studies, Vol. 33 No. 3, pp. 497-514.

*Magness, V. (2006), "Strategic posture, financial performance and environmental disclosure: an empirical test of legitimacy theory", Accounting, Auditing \& Accountability Journal, Vol. 19 No. 4, pp. 540-563.

Minkov, M. and Hofstede, G. (2011) "The evolution of Hofstede's doctrine", Cross Cultural Management: An International Journal, Vol. 18 No. 1, pp. 10 - 20.

Moller, A. and Jennions, M. (2001), “Testing and adjusting for publication bias", Trends in Ecology Evolution, Vol. 16, pp. 580-586.

*Moore, G. (2001), "Corporate social and financial performance: an investigation in the U.K. supermarket industry”, Journal of Business Ethics, Vol. 34 No. (3/4), pp. 299-315.

*Murcia, F. D. R. and De Souza, F. C. (2008), "Discretionary-based disclosure: the case of social and environments reporting in Brazil", Journal of Education and Research in Accounting, Vol. 3 No. 2, pp. 72-887.

Naser, K., Al-Hussaini, A., Al-Kwari, D. and Nuseibeh R. (2006), "Determinants of corporate social disclosure in developing countries: The case of Qatar", Advances in International Accounting, Vol. 19, pp. 1-23. 
Orens, R., Aerts, W. and Cormier, D. (2010), "Web-based non-financial disclosure and cost of finance", Journal of Business Finance \& Accounting, Vol. 37 No. (9) \& (10), pp. 10571093.

Orij R. (2010), "Corporate social disclosures in the context of national cultures and stakeholder theory", Accounting, Auditing \& Accountability Journal, Vol. 23 No. 7, pp. 868889.

Orwin, R. G. (1983), “A fail-safe N for effect size in meta-analysis”, Journal of Educational Statistics, Vol. 8, pp. 157-159.

Parket, IR. and Eilbrit, H. (1975), "The practice of business social responsibility: the underlying factors", Business Horizons, Vol. 18 No.4, pp. 5-10.

*Pahuja, S. (2009), "Relationship between environmental disclosures and corporate characteristics: a study of large manufacturing companies in India", Social Responsibility Journal, Vol. 5 No. 2, pp. 227- 244.

*Patten, D. M. (1992), "Intra-industry environmental disclosures in response to the Alaskan Oil Spill: A note on legitimacy theory", Accounting, Organizations and Society, Vol. 15 No. $5,471-475$.

*Prado-Lorenzo, J. M., Gallego-Alvarez, I. and Garcia-Sanchez I M. (2009), "Stakeholder engagement and corporate social responsibility reporting: the ownership structure effect", Corporate Social Responsibility and Environmental Management, Vol. 16 No. 2, pp. 94107.

*Reverte, C. (2009), "Determinants of corporate social responsibility disclosure ratings by Spanish listed firms”, Journal of Business Ethics, Vol. 88 No. 2, pp. 351-366.

*Richardson, A. J. and Welker, M. (2001), "Social disclosure, financial disclosure and the cost of equity capital", Accounting, Organisations and Society, Vol. 26 No. 7, pp. 597- 616.

Richardson, A. J., Welker, M. and Hutchinson. I. R. (1999), "Managing capital market reactions to corporate social responsibility", International Journal of Management Reviews, Vol. 1, 17-43.

*Rashid, A. and Lodh, S. (2009), "The influence of ownership structures and board practices on corporate social disclosures in Bangladesh", Research in Accounting in Emerging Economies, Vol. 8, pp. 211-237.

*Roberts, R. W. (1992), "Determinants of corporate social disclosure: an application of stakeholder theory", Accounting, Organizations and Society, Vol. 17 No. 6, pp. 595-612.

Ringov, D. and Zollo, M. (2007), "The impact of national culture on corporate social performance", Corporate Governance, Vol. 7, pp. 476-485.

Rosenthal, R. (1979), "The "file drawer problem" and tolerance for null results", Psychological Bulletin, Vol. 86 No. 3, pp. 638-641.

Rosenthal, R. (1991), Meta-Analytic Procedures for Social Research. Applied Social Research Methods Series: 6 Newbury Park: Sage. 
*Said, R., Zainuddin, Y. and Haron, H. (2009), "The relationship between corporate social responsibility disclosure and corporate governance characteristics in Malaysian public listed companies", Social Responsibility Journal, Vol. 5 No. 2, pp. 212 - 226.

Salter, S., Sharp, D. and Chen, Y. (2013), "The moderating effects of national culture on escalation of commitment", Advances in Accounting Incorporating Advances in International Accounting, Vol. 29, pp. 161-169.

*Samaha, K. and Dahawy, K. (2011), "An empirical analysis of corporate governance structures and voluntary corporate disclosure in volatile capital markets: The Egyptian experience", Int. J. Accounting, Auditing and Performance Evaluation, Vol 7 No. (1/2), pp. 61-93.

Schneider, S. C. and DeMeyer, A. (1991), "Interpreting and responding to strategic issues: The impact of national culture”, Strategic Management Journal, Vol. 12, pp.307-320.

Singhvi, S. (1968), "Characteristics and implications of inadequate disclosure: a case study of India”, International Journal of Accounting, Vol. 3 No. 2, pp. 29- 43.

*Siregar, S. V. and Bachtiar, Y. (2010), "Corporate social reporting: empirical evidence from Indonesia Stock Exchange", International Journal of Islamic and Middle Eastern Finance and Management, Vol. 3 No. 3, pp. 241 - 252.

*Smith, M., Yahya, K. and Amiruddin, A. H. (2007), "Environmental disclosure and performance reporting in Malaysia", Asian Review of Accounting, Vol. 15 No. 2, pp. 185199.

Stanley, T.D. (2005), "Beyond Publication Bias", Journal of Economic Surveys, Vol. 19 No. 3, pp. 309-345.

*Stanwick, S. D. and Stanwick, P. A. (1998a), "The relationship between corporate social performance, and organizational size, financial performance, and environmental performance: An empirical examination", Journal of Business Ethics, Vol. 17, pp. 195-204.

*Stanny, E. and Ely, K. (2008), "Corporate environmental disclosures about the effects of climate change", Corporate Social Responsibility and Environmental Management, Vol. 15, pp. 338-348.

Stulz, R.M. and Williamson, R. (2003), "Culture, openness, and finance", Journal of Financial Economics, Vol. 70 No. 3, pp. 313-349.

*Tagesson, T., Blank, V., Broberg, P. Collin, S. O. (2009), "What explains the extent and content of social and environmental disclosures on corporate websites: a study of social and environmental reporting in Swedish listed corporations", Corporate Social Responsibility and Environmental Management, Vol. 16, pp. 352-364.

*Talebniaa, G., Vakilifarda, H.,Yaghoubnezhad, A. and Alikhani, R. (2013), "Corporate social and environmental disclosure in developing countries: evidence from Iran", Management Science Letters, Vol. 3, pp. 135-146. 
Tice, D.M. and Baumeister, R.F. (2004), "Masculinity inhibits helping in emergencies: personality does predict the bystander effect', Journal of Personality and Social Psychology, Vol. 49 No. 2, pp. 420-8.

Tsoutsoura, M. (2004), “Corporate social responsibility and financial performance”, Working paper, Haas School of Business, University of California, Berkeley.

*Toms, J. S. (2002), "Firm resources, quality signals and the determinants of corporate environmental reputation: some UK evidence", British Accounting Review, Vol. 34, pp. 257282 .

Ullmann, A. A. (1985), "Data in search of a theory: a critical examination of the relationships among social disclosure, and economic performance of US firms", Academy of Management Review, Vol. 10 No. 3, pp. 540-557.

*Uwuigbe, U. and Egbide B. (2012), "Corporate social responsibility disclosures in Nigeria: A study of listed financial and non-financial firms", Journal of Management and Sustainability, Vol. 2 No.1, pp. 160-169.

Van der Laan Smith, J., Adikhari, A. and Tondkar, R.H. (2005), "Exploring differences in social disclosures internationally: a stakeholder perspective", Journal of Accounting and Public Policy, Vol. 24 No. 2, pp. 123-151.

Vitell, S. J., Nwachukwu, S. L. and J. H. Barnes. (1993), "The effects of culture on ethical decision-making: An application of Hofstede's typology”. Journal of Business Ethics, Vol. 12, pp. 753-60.

Williams, G. and Zinkin, J. (2008), "The effect of culture on consumers' willingness to punish irresponsible corporate behaviour: applying Hofstede's typology to the punishment aspect of corporate social responsibility”, Business Ethics: A European Review, Vol. 17 No.2, pp. 210- 226.

Zarzeski, M. T. (1996), "Spontaneous harmonization effects of culture and market forces on accounting disclosure practices", Accounting Horizons, Vol.10, pp. 18-37.

Zimmerman, M. A. and Zeitz, G. J. (2002), "Beyond survival: achieving new venture growth by building legitimacy", Academy of Management Review, Vol. 27, pp. 414-431 
Table 1. Sample selection

\begin{tabular}{lrr}
\hline & Number of studies & Percentage \\
\hline Initial sample & 80 & $100 \%$ \\
\hline Criteria leading to exclusion of studies & $(22)$ & 27.500 \\
Studies providing only descriptive statistics (a) & $(10)$ & 12.500 \\
Studies with cross-national samples (b) & 48 & 60.000 \\
Final sample & Number of studies & Percentage \\
\hline Publication quality & 34 & 70.833 \\
& 14 & 29.167 \\
Ranked journals & 48 & $100 \%$ \\
Decent Journals & & \\
Total & & \\
\hline (a) Antonites and De Villiers (2003), De Villiers and Barnard (2000),Parket and Eilbrit (1975); \\
(b) Maignan and Ralston (2002).
\end{tabular}


Table 2. Studies included in the Meta-analysis

\begin{tabular}{|c|c|c|c|c|c|c|c|c|c|}
\hline Study & Country & $\begin{array}{l}\text { No. of } \\
\text { observations }\end{array}$ & $\begin{array}{l}\text { Reporting } \\
\text { years }\end{array}$ & Individualism & Masculinity & $\begin{array}{l}\text { Long term } \\
\text { orientation }\end{array}$ & $\begin{array}{l}\text { Proxy for } \\
\text { profitability }\end{array}$ & Effect size & $\begin{array}{l}\begin{array}{l}\text { Source of } \\
\text { information }\end{array} \\
\end{array}$ \\
\hline Freedman and Jaggi & USA & 109 & 1973-1974 & 91 & 62 & 29 & ROE & -0.041 & Table. 2, p. 173 \\
\hline Cowen el al. (1987) & USA & 134 & 1978 & 91 & 62 & 29 & ROE & -0.010 & Table. p. 119 \\
\hline Freedman and Jaggi & USA & 101 & 1979 & 91 & 62 & 29 & ROE & -0.034 & Table. 1, p. 50 \\
\hline Patten (1991) & USA & 128 & 1985 & 91 & 62 & 29 & ROA & 0.060 & Table. 1, p. 304 \\
\hline Roberts (1992) & USA & 101 & 1984-1986 & 91 & 62 & 29 & ROE & 0.203 & Table. 3, p. 607 \\
\hline Hackston \& Milne (1996) & $\begin{array}{l}\text { New } \\
\text { 7ealand }\end{array}$ & 50 & 1992 & 79 & 58 & 30 & ROE & -0.079 & Table 6, p. 92 \\
\hline Stanwick \& Stanwick & USA & 121 & 1992 & 91 & 62 & 29 & ROS & 0.389 & Table. 2, p. 201 \\
\hline Cormier \& Magnan & Canada & 33 & 1986-1993 & 80 & 52 & 23 & ROA & 0.040 & Table 2, p. 442 \\
\hline Alnajjar (2000) & USA & 451 & 1990 & 91 & 62 & 29 & ROE & -0.152 & Table. 4, p. 185 \\
\hline Bewly \& Li (2000) & Canada & 188 & 1993 & 80 & 52 & 23 & ROA & 0.060 & Table. 2, p. 214 \\
\hline Cormier \& Gordon & Canada & 36 & 1985-1996 & 80 & 52 & 23 & ROE & 0.009 & Table. 5, p. 605 \\
\hline Moore (2001) & UK & 24 & 1997-1999 & 89 & 66 & 25 & Average & -0.519 & Table., p. 308 \\
\hline Richardson \& Welker & Canada & 324 & 1990-1992 & 80 & 52 & 23 & ROE & -0.023 & Table 2, p. 604 \\
\hline Chau \& Gray (2002) & Hong Kong & 60 & 1997 & 25 & 57 & 96 & ROS & 0.125 & Table 2, p. 255 \\
\hline Chau \& Gray (2002) & Singapore & 62 & 1997 & 20 & 48 & 48 & ROS & 0.000 & Table 2, p. 256 \\
\hline Hail (2002) & Switzerland & 73 & 1997 & 68 & 70 & 40 & ROE & 0.129 & Table 3, p. 757 \\
\hline Toms (2002) & UK & 126 & 1997 & 89 & 66 & 25 & ROE & 0.153 & Table. 3.p. 272 \\
\hline Ahmad et al (2003) & Malaysia & 299 & 1999 & 26 & 50 & NA & ROA & 0.021 & Table. 4 , p. 83 \\
\hline Cormier and Magnan & France & 246 & 1997 & 71 & 43 & 39 & ROE & -0.070 & Table. 2, p. 25 \\
\hline Al-Tuwaijri et al. (2004) & USA & 198 & 1994 & 91 & 62 & 29 & ROS & 0.085 & Table. 2, p. 461 \\
\hline Cormier et al. (2005) & Germany & 304 & 1992-1998 & 67 & 66 & 31 & FMR & 0,029 & Table. 3 , p. 25 \\
\hline Haniffa \& Cooke (2005) & Malaysia & 139 & 2002 & 26 & 50 & NA & ROE & 0.333 & Table. 5, p. 413 \\
\hline Magness (2006) & Canada & 41 & 1995 & 80 & 52 & 23 & ROA & -0.174 & Table. 3, p. 551 \\
\hline Ghazali (2007) & Malaysia & 87 & 2001 & 26 & 50 & NA & ROA & 0.154 & Table. 5, p. 260 \\
\hline Smith et al (2007) & Malaysia & 40 & 2001 & 26 & 50 & NA & ROE & -0.416 & Table. 2, p. 193 \\
\hline Clarkson et al. (2008) & USA & 191 & 2004 & 91 & 62 & 29 & ROA & 0.040 & Table. 3 (B), p. \\
\hline Branco \& Rodrigues & Portugal & 49 & 2003 & 27 & 31 & 30 & ROA & -0.077 & Table 5, pp. 697 \\
\hline Stanny and Ely (2008) & USA & 494 & 2006 & 91 & 62 & 29 & ROA & -0.040 & Table. 3. B, p. \\
\hline Said et al. (2009) & Malaysia & 150 & 2006 & 26 & 50 & NA & ROE & 0.157 & Table. 7, p. 222 \\
\hline Jinfeng \& Huifeng (2009) & China & 248 & 2006 & 20 & 66 & 118 & ROE & 0.053 & Table 6, p. 20 \\
\hline Pahuja (2009) & India & 91 & 1999-2002 & 48 & 56 & 61 & ROS & 0.189 & Table 4, p. 238 \\
\hline Reverte (2009) & Spain & 46 & $2005-2006$ & 51 & 42 & 19 & ROA & 0.101 & Table 4, p. 362 \\
\hline Prado-Lorenzo et al & Spain & 99 & 2007 & 51 & 42 & 19 & ROE & 0.040 & Table. 3, p. 103 \\
\hline
\end{tabular}

Notes: CSED: Corporate social and environmental disclosure; NA: not available. ROA: net profit/ total assets; ROE: net profit/ equity; ROS: net profit/ total sales.

In Moore (2001), corporate profitability is measured as the average of several financial performance measures denoted as Average in the table.

In Cormier et al. (2005), corporate performance is measured as firm's annual stock market return (FMR). 
Table.2. Continued

\begin{tabular}{|c|c|c|c|c|c|c|c|c|c|}
\hline Study & Country & $\begin{array}{l}\text { No. of } \\
\text { observations }\end{array}$ & Reporting years & Individualism & Masculinity & $\begin{array}{l}\text { Long term } \\
\text { orientation }\end{array}$ & $\begin{array}{l}\text { Proxy for } \\
\text { profitability }\end{array}$ & $\begin{array}{l}\text { Effect } \\
\text { size }\end{array}$ & Source of information \\
\hline Rashid \& Lodh, (2009) & Bangladesh & 84 & 2003-2007 & 20 & 55 & 40 & ROA & 0.160 & Table. 7. P. 226 \\
\hline Hussainey et al. (2009) & Egypt & 111 & $2005-2010$ & 25 & 45 & NA & ROE & 0.230 & Table. 5, p. 28 \\
\hline Liu \& Anbumozhi (2009) & China & 175 & 2006 & 20 & 66 & 118 & ROE & 0.125 & Table. 4, p. 598 \\
\hline Murcia \& De Souza (2009) & Brazil & 99 & 2007 & 38 & 49 & 65 & ROE & 0.192 & Table. 1, p. 10 \\
\hline Tagesson et al. (2009) & Sweden & 267 & 2006 & 71 & 5 & 20 & ROE & 0.171 & Table. 4, p. 359 \\
\hline Siregar \& Bachtiar (2010) & Indonesia & 87 & 2003 & 14 & 46 & NA & ROE & -0.025 & Table 2, p. 248, panel \\
\hline Khan (2010) & Bangladesh & 60 & 2007-2008 & 20 & 55 & 40 & ROE & 0.193 & Table 7, p. 99 \\
\hline $\begin{array}{l}\text { da Silva Monteiro \& Aibar- } \\
\text { Guzmán (2010) }\end{array}$ & Portugal & 327 & 2002-2004 & 27 & 31 & 30 & ROE & 0.064 & Table. 4, P. 197 \\
\hline Gamerschlag et al. (2010) & Germany & 482 & 2005-2008 & 67 & 66 & 31 & ROE & -0.004 & Table. 4, p. 17 \\
\hline Li \& Zang (2010) & China & 692 & 2008 & 20 & 66 & 118 & ROE & 0.159 & Tables $3 \&$ 4. P.638 \\
\hline Dawkins \& Fraas (2011) & USA & 344 & 2008 & 91 & 62 & 29 & ROA & 0.001 & Table. 2, p. 312 \\
\hline Samaha and Dahawy (2011) & Egypt & 100 & 2006 & 25 & 45 & NA & ROE & 0.063 & Table., p.79 \\
\hline Cho et al. (2012) & USA & 119 & 2004 & 91 & 62 & 29 & ROA & 0.010 & Table. 7, p. 500 \\
\hline Uwuigbe \& Egbide (2012) & Nigeria & 41 & 2008-2009 & 30 & 60 & 16 & ROA & 0.667 & Table. 2, p. 167 \\
\hline Khan et al. (2013) & Bangladesh & 580 & 2005-2009 & 20 & 55 & 40 & ROA & 0.371 & Table. 3, P. 10 \\
\hline Talebinia et al. (2013) & Iran & 396 & 2006-2010 & 41 & 43 & NA & ROA & 0.042 & Table. 143 \\
\hline
\end{tabular}


Table 3. Profitability and CSED

\begin{tabular}{|c|c|c|c|c|c|c|c|c|c|c|}
\hline $\begin{array}{l}\text { Independent } \\
\text { variable }\end{array}$ & $\begin{array}{l}\text { Sample size } \\
\mathrm{N}\end{array}$ & $\begin{array}{l}\text { Studies } \\
\mathrm{K}\end{array}$ & $\begin{array}{l}\text { Mean } \\
\text { correlation } \\
(\bar{r})\end{array}$ & $\begin{array}{l}\text { Observed } \\
\text { variance } \\
\left(S_{r}^{2}\right)\end{array}$ & $\begin{array}{l}\text { Estimated } \\
\text { error variance } \\
\left(S_{e}^{2}\right)\end{array}$ & $\begin{array}{l}\text { Percentage } \\
\text { explained } \\
\left(S_{e}^{2} / S_{r}^{2}\right)\end{array}$ & Z-Statistic & $\begin{array}{l}95 \% \text { confidence } \\
\text { interval }\end{array}$ & $\chi_{k-1}^{2}$ & $\begin{array}{l}\text { File } \\
\text { Drawer } \\
0.05\end{array}$ \\
\hline $\begin{array}{l}\text { Overall meta- } \\
\text { analysis } \\
\text { Moderating factors }\end{array}$ & 8986 & 49 & $0.072 * * *$ & 0.019 & 0.005 & 27.138 & 3.619 & $0.033 ; 0.112$ & $180.557 * * *$ & 69 \\
\hline High individualism & 4864 & 25 & 0.011 & 0.012 & 0.005 & 43.138 & 0.538 & $-0.031 ; 0.054$ & $57.952 * * *$ & - \\
\hline Low individualism & 4122 & 24 & $0.145^{* * *}$ & 0.019 & 0.005 & 28.370 & 5.066 & $0.088 ; 0.212$ & $84.594 * * *$ & 63 \\
\hline High masculinity & 4857 & 24 & $0.045^{*}$ & 0.016 & 0.004 & 29.570 & 1.717 & $-0.006 ; 0.096$ & $81.163 * * *$ & - \\
\hline Low masculinity & 4129 & 25 & $0.105^{* * *}$ & 0.021 & 0.005 & 27.250 & 3.577 & $0.047 ; 0.163$ & $91.741 * * *$ & 41 \\
\hline $\begin{array}{l}\text { High long term } \\
\text { orientation }\end{array}$ & 3682 & 17 & $0.118^{* * * *}$ & 0.017 & 0.004 & 25.580 & 3.702 & $0.056 ; 0.181$ & $66.455^{* * * *}$ & 34 \\
\hline $\begin{array}{l}\text { Low long term } \\
\text { orientation }\end{array}$ & 3803 & 23 & 0.019 & 0.017 & 0.006 & 33.817 & 0.700 & $-0.035 ; 0.074$ & $68.011 * * *$ & - \\
\hline
\end{tabular}

Notes: CSED: Corporate social and environmental disclosure. * significant at $10 \%$, **significant at $5 \%$, ***significant at $1 \%$. The medians are as follows: 51 for individualism, 55 for masculinity, and 29 for long term orientation. 
Table 4. Additional and sensitivity analysis for profitability and CSED

\begin{tabular}{|c|c|c|c|c|c|c|c|c|c|c|}
\hline $\begin{array}{l}\text { Independent } \\
\text { variable }\end{array}$ & $\begin{array}{l}\text { Sample size } \\
\mathrm{N}\end{array}$ & $\begin{array}{l}\text { Studies } \\
\mathrm{K}\end{array}$ & $\begin{array}{l}\text { Mean } \\
\text { correlation } \\
(\bar{r})\end{array}$ & $\begin{array}{l}\text { Observed } \\
\text { variance } \\
\left(S_{r}^{2}\right)\end{array}$ & $\begin{array}{l}\text { Estimated } \\
\text { error variance } \\
\left(S_{e}^{2}\right)\end{array}$ & $\begin{array}{l}\text { Percentage } \\
\text { explained } \\
\left(S_{e}^{2} / S_{r}^{2}\right)\end{array}$ & Z-Statistic & $\begin{array}{l}95 \% \text { confidence } \\
\text { interval }\end{array}$ & $\chi_{k-1}^{2}$ & $\begin{array}{c}\text { File } \\
\text { Drawer } \\
0.05\end{array}$ \\
\hline \multicolumn{11}{|c|}{ A- Profitability and CSED excluding US studies } \\
\hline $\begin{array}{l}\text { Overall meta- } \\
\text { analysis }\end{array}$ & 6495 & 37 & $0.100 * * *$ & 0.019 & 0.005 & 29.053 & 4.403 & $0.056 ; 0.145$ & $127.305 * * *$ & 56 \\
\hline \multicolumn{11}{|l|}{ Moderating factors } \\
\hline High individualism & 3104 & 18 & $0.037 *$ & 0.008 & 0.006 & 68.125 & 1.710 & $-0.005 ; 0.079$ & $26.422 *$ & - \\
\hline Low individualism & 3391 & 19 & $0.158 * * *$ & 0.022 & 0.005 & 24.176 & 4.645 & $0.091 ; 0.224$ & $78.589 * * *$ & 57 \\
\hline $\begin{array}{l}\text { High masculinity } \\
\text { Low masculinity }\end{array}$ & $\begin{array}{l}3891 \\
2604\end{array}$ & $\begin{array}{l}20 \\
17\end{array}$ & $\begin{array}{l}0.118 * * * \\
0.074 * * *\end{array}$ & $\begin{array}{l}0.022 \\
0.014\end{array}$ & $\begin{array}{l}0.005 \\
0.006\end{array}$ & $\begin{array}{l}22.666 \\
46.761\end{array}$ & $\begin{array}{l}3.555 \\
2.592\end{array}$ & $\begin{array}{l}0.035 ; 0.183 \\
0.018 ; 0.129\end{array}$ & $\begin{array}{l}88.237 * * * \\
36.354 * * *\end{array}$ & $\begin{array}{r}33 \\
9\end{array}$ \\
\hline $\begin{array}{l}\text { High long term } \\
\text { orientation }\end{array}$ & 2520 & 13 & $0.164 * * *$ & 0.018 & 0.005 & 26.294 & 4.344 & $0.090 ; 0.238$ & $49.440 * * *$ & 30 \\
\hline $\begin{array}{l}\text { Low long term } \\
\text { orientation }\end{array}$ & 2474 & 15 & 0.038 & 0.013 & 0.006 & 47.456 & 1.319 & $-0.018 ; 0.095$ & $31.542 * * *$ & - \\
\hline \multicolumn{11}{|c|}{ B- Additional analysis for profitability and CSED } \\
\hline $\begin{array}{l}\text { Overall meta- } \\
\text { analysis } \\
\text { Additional tests }\end{array}$ & 8986 & 49 & $0.072 * * *$ & 0.019 & 0.005 & 27.138 & 3.619 & $0.033 ; 0.112$ & $180.557 * * *$ & 69 \\
\hline ROA & 3398 & 17 & $0.089 * * *$ & 0.023 & 0.005 & 21.042 & 2.410 & $0.016 ; 0.162$ & $80.790^{* * *}$ & 21 \\
\hline ROE & 4728 & 25 & $0.056^{* *}$ & 0.015 & 0.005 & 33.534 & 2.249 & $0.007 ; 0.105$ & $74.551^{* * *}$ & 15 \\
\hline ROS & 411 & 4 & $0.101 * * *$ & 0.003 & 0.009 & 100.000 & 3.435 & $0.043 ; 0.158$ & 1.451 & 2 \\
\hline Before 2000 & 3428 & 23 & 0.006 & 0.016 & 0.006 & 39.966 & 0.232 & $-0.046 ; 0.059$ & $57.547 * * *$ & - \\
\hline $\begin{array}{l}\text { After } 2000 \\
\text { (including 2000) }\end{array}$ & 5467 & 25 & $0.112 * * *$ & 0.017 & 0.004 & 25.387 & 4.254 & $0.061 ; 0.164$ & $98.473^{* * *}$ & 45 \\
\hline High quality journals & 6494 & 34 & $0.081 * * *$ & 0.020 & 0.005 & 25.666 & 3.318 & $0 ; 033 ; 0.128$ & $132.469 * * *$ & 45 \\
\hline Low quality journals & 2492 & 15 & 0.052 & 0.018 & 0.005 & 32.166 & 1.486 & $-0.016 ; 0.121$ & $46.704 * * *$ & - \\
\hline
\end{tabular}

Notes: CSED: Corporate social and environmental disclosure. The new medians after excluding US studies are as follows: 30 for individualism, 50 for masculinity, and 29 for long term orientation. ROA: net profit/ total assets; ROE: net profit/ equity; ROS: net profit/ total sales. * significant at $10 \%$, **significant at $5 \%$, $* * *$ significant at $1 \%$. 
